medRxiv preprint doi: https://doi.org/10.1101/2020.05.28.20116400; this version posted June 3, 2020. The copyright holder for this preprint (which was not certified by peer review) is the author/funder, who has granted medRxiv a license to display the preprint in perpetuity. It is made available under a CC-BY-NC-ND 4.0 International license.

\title{
Incidence and risk factors of kidney impairment on patients with COVID-19:
}

a systematic review and meta-analysis

Qixin Yang ${ }^{1,2^{*}}$, Xiyao Yang ${ }^{1}$

${ }^{1}$ National Clinical Research Center for Geriatric Disorders, Xiangya Hospital, Central South University, Changsha, Hunan, China

${ }^{2}$ Department of Cardiovascular Medicine, Xiangya Hospital, Central South University, Changsha, Hunan, China

Address for correspondence:

Qixin Yang MD

Department of Cardiovascular Medicine.

Xiangya Hospital, Central South University,

Xiangya Rd 87, Changsha, Hunan, China ,410008

E-mail: yangqixin@csu.edu.cn

Phone: +86-152-0089-7795

\section{DISCLOSURES}

No authors have any conflicts of interest to disclose

\section{KEYWORDS}

COVID-19; SARS-CoV-2; clinical features; laboratory; acute kidney injury (AKI); kidney dysfunction. 
medRxiv preprint doi: https://doi.org/10.1101/2020.05.28.20116400; this version posted June 3, 2020. The copyright holder for this preprint

\section{$\underline{\text { ABSTRACT }}$}

Background: The novel coronavirus is pandemic around the world. Several researchers have given the evidence of impacts of COVID-19 on the respiratory, cardiovascular and gastrointestinal system. Studies still have debated on kidney injury of COVID-19 patients. The purpose of the meta-analysis was to evaluate the association of kidney impairment with the development of COVID-19.

Methods: The PubMed, Embase and MedRxiv databases were searched until April 1, 2020. We extracted data from eligible studies to summarize the clinical manifestations and laboratory indexes of kidney injury on COVID-19 infection patients and further compared the prevalence of acute kidney injury (AKI) and the mean differences of three biomarkers between in ICU/severe and non-ICU/non-severe cases. Heterogeneity was evaluated using the $\mathrm{I}^{2}$ method.

Results: In the sum of 19 studies with 4375 patients were included in this analysis. The pooled prevalence of AKI, increased serum creatinine (Scr), increased blood urea nitrogen (BUN), increased D-dimer, proteinuria and hematuria in patients with COVID-19 were 7.7\%, 6.6\%, $6.2 \%, 49.8 \%, 42 \%$ and $30.3 \%$ respectively. Moreover, the means of Scr, BUN and D-dimer were shown 6 -folds, 1.8 -folds and 0.68 -folds, respectively, higher in ICU/severe cases than in corresponding non-ICU/non-severe patients. The prevalence of AKI was about 17 folds higher in ICU/severe patients compared with the non-ICU/non-severe cases.

Conclusions: Overall, we assessed the incidences of the clinic and laboratory features of kidney injury in COVID-19 patients. And kidney dysfunction may be a risk factor for COVID-19 patients developing into the severe condition. In reverse, COVID-19 can also cause damage to the kidney. 
medRxiv preprint doi: https://doi.org/10.1101/2020.05.28.20116400; this version posted June 3, 2020. The copyright holder for this preprint

\section{INTRODUCTION}

In December 2019, a group of pneumonia cases caused by an unknown virus was first reported in Wuhan, Hubei province, China ${ }^{1,2}$. Those cases have similar symptoms of virus infection, including fever, fatigue, and dry cough as well as myalgia, dyspnea ${ }^{1,2}$. WHO has officially named this novel coronavirus as severe acute respiratory syndrome coronavirus 2 (SARS- CoV2) after the pathogen was isolated and identificated ${ }^{3,4}$. Nowadays, this novel coronavirus is causing COVID-19 epidemic on the international scale due to its highly transmissive and contagiousness, compared with other coronavirus infection diseases including Middle East Respiratory Syndrome (MERS) and Severe Acute Respiratory Syndrome (SARS) ${ }^{5}$. As of April 21,2020 , a total of 2531804 confirmed cases involved in 185 countries and regions, and the numbers continue to rise. And SARS-CoV-2 mainly causes a series of the clinical characteristics in the respiratory system, such as asymptomatic infection, mild upper respiratory tract illness, severe acute respiratory distress syndrome, respiratory failure and even death ${ }^{1,2,6}$. The pathogenic mechanism of SARS-CoV-2 is binding to membrane ACE2 for entering into pulmonary cells ${ }^{4}$. And ACE2 is widely distributing in several vital organs including lung, heart, kidney and intestine ${ }^{7}$. Apart from the respiratory symptom, SARS-CoV-2 also caused cardiovascular damage, not only led to acute cardiac injury (ACI) with an increased highsensitivity cardiac troponin I (hs-cTnI) in clinic ${ }^{1}$. On the other hands, patients with pre-existing cardiovascular diseases (CVDs) are more likely developed into the severe condition and even contribute to highly mortality ${ }^{1,8,9}$. Moreover, SARS-CoV-2 has an impact on the gastrointestinal system, bringing symptom like diarrhea with a statistically significant difference, which may be underestimated on clinical diagnosis ${ }^{10}$. Further study has proved that SARS-CoV-2 infects 
medRxiv preprint doi: https://doi.org/10.1101/2020.05.28.20116400; this version posted June 3, 2020. The copyright holder for this preprint

the gastrointestinal tract, the results of histologic and immunofluorescent staining of gastrointestinal tissues from COVID-19 patients were showed that the existence of ACE2 receptor and viral nucleocapsid protein in the cytoplasm of gastric, duodenal, and rectum glandular epithelial cell. ${ }^{11}$

Therefore, we are also concerned whether SARS-CoV-2 causes kidney dysfunction and whether COVID-19 patients with kidney impairment are at a higher risk. Some clinical studies have focus attention on kidney injury of COVID-19 patients. Zhen Li et al. has shown that a large proportion of COVID-19 patients is accompanied by kidney dysfunction, including proteinuria, hematuria, increased serum creatine and blood urea nitrogen ${ }^{12}$. Yichun Cheng also demonstrated that kidney injury is associated with in-hospital death of COVID-19 patients ${ }^{13}$. However, Luwen Wang thought that SARS-CoV-2 did not cause obviously kidney damage to patients $^{14}$. With issue arising, a meta-analysis with large clinical samples is desperately warranted to produce a convincible result.

\section{METHODS}

Our study was conducted following Preferred Reporting Items for Systematic Reviews and Meta-Analyses of individual participant data (the PRISMA-IPD) statement ${ }^{15}$

\section{Data source, search strategy and selection criteria}

PubMed, EMBASE, and MedRxiv databases were applied for searching studies published from December 2019 to April 2020 in China. To identify all the articles displaying the renal injury and impairment in COVID -19, we used the following keywords or search terms alone and in combination: "novel coronavirus", "China", "HCoV", "nCoV" "Wuhan", "COVID-19" 
medRxiv preprint doi: https://doi.org/10.1101/2020.05.28.20116400; this version posted June 3, 2020. The copyright holder for this preprint

"SARS-CoV-2", "clinical”, "laboratory", "kidney”, "Acute Kidney Injury”, "proteinuria” and "hematuria". Detailed search strategies were illustrated in Figure 1.

Inclusion criteria are as follows:(1) comparative studies: randomized controlled trials RCTs or non-RCTs published only restricted in English; (2) patients in the studies should be confirmed to have been infected by COVID-19; (3)studies containing information about the clinical or laboratory characteristics (4) studies containing the comorbidities of kidney dysfunction and the outcome of kidney impairment. Exclusion criteria are (1) studies that less than 10 patients were included; (2) case reports, editorials, comments, non-clinical studies, reviews, studies without reliable information; (3) studies with special populations (e.g., only focused on children or severe or death cases).

\section{Data extraction and study quality assessment}

Prevalence of comorbidities and clinical manifestations of kidney damage, including AKI, proteinuria and hematuria, together with laboratory indexes of kidney impairment (confirmed by elevation of Scr, BUN and D-dimer) were extracted from the identified studies. The subgroup measure parameters were to compare the incidences of AKI and the mean differences of the three laboratory indicators among ICU and Non-ICU cases (severe and non-severe data as the second choice if ICU data was not provided). Cochrane Collaboration's tool was applied to evaluate the risk of bias.

\section{Statistical analysis}

All analyses were performed using OpenMeta Analyst (version 12.11.14) (http://www.cebm.brown.edu/openmeta/) and Review Manager (version 5.3). Forest plots were used to depict the incidences of clinical and laboratory features of kidney dysfunction of 
medRxiv preprint doi: https://doi.org/10.1101/2020.05.28.20116400; this version posted June 3, 2020. The copyright holder for this preprint

(which was not certified by peer review) is the author/funder, who has granted medRxiv a license to display the preprint in perpetuity.

It is made available under a CC-BY-NC-ND 4.0 International license.

COVID-19 patients. The odds ratio (OR, 95\% confidence intervals (CI)) and mean differences

(MD, 95\% confidence intervals (CI)) were used to illustrate the comprehensive effects of COVID-19 occurring in ICU/severe patients and non-ICU/non-severe patients. And $\mathrm{I}^{2}$ statistics were used to assess the statistical heterogeneity. The fixed-effect model was used if $\mathrm{I}^{2}<50 \%$ and the random effect model was used if $\mathrm{I}^{2} \geq 50 \%{ }^{8}$. The funnel plots were used to show the risk of publication bias.

\section{RESULTS}

\section{Selected literature and studies characteristics}

At initially, we have searched a total of 838 studies after 231 duplicate studies were identified.

Following reviewed the titles and abstracts, we ruled out 772 non-clinical research, reviews, comments, case reports and studies of participants less than 10. With the remaining 66 documents, we reviewed and evaluated the whole articles with detailed information. We further excluded 47 records for multiple reasons such as lacking enough clinical information and only demonstrated the exceptional cases. In the result, we identified 19 eligible studies meeting our inclusion criteria for our meta-analysis, including 4375 COVID-19 positive patients (Figure 1). All of them were retrospective, descriptive observational studies including 14 single-center and 5 multiple-center studies, which were mainly conducted between December 2019 and March 2020.

The epidemiological and clinical characteristics of COVID-19 from 19 included studies were illustrated in Table 1. And we also described the prevalence of the complications of kidney injury on clinic and laboratory features. The majority of studies were performed in Wuhan and 
medRxiv preprint doi: https://doi.org/10.1101/2020.05.28.20116400; this version posted June 3, 2020. The copyright holder for this preprint

other cities in China. Among all selected studies, the infected men accounted for a more substantial proportion than women and the men to women ratio was 1.2. The mean age of the participants was 52.5 years $(95 \% \mathrm{CI}, 49.7-55.4)$.

\section{AKI and biomarkers of kidney dysfunction}

Our outcome of meta-analysis for identified studies suggested that the AKI occurred $7.7 \%(95 \%$ CI 4.5-10.9\%) in COVID-19 patients (Figure 2A). According to the Kidney Disease: Improving Global Outcomes (KDIGO) guidelines ${ }^{16}$ and the limited clinical and laboratory information acquired from those studies, we used several indicators to display the comorbidities of kidney dysfunction. And the most prevalent laboratory indexes were increased Scr $(6.6 \%$, 95\% CI 3.0-10.2\%) (Figure 2B), increased BUN (6.2\%, 95\% CI 2.4-10.1\%) (Figure 2C) and increased D-dimer (49.8\%, 95\% CI 35.4-64.2\%) (Figure 2D). We included D-dimer for the reason that the elimination of D-dimer protein partially happens through kidney and high Ddimer is associated with the dysfunction of kidney ${ }^{17}$. However, the $\mathrm{I}^{2}$ index ranging from $82 \%$ to $98 \%$ revealed significant heterogeneity in the evaluation of AKI, Scr, BUN and D-dimer among the included studies $(\mathrm{P}<0.001)$ (Figure 2 A-D).

\section{Risk stratification factors for COVID-19}

To identify the risk factors for critical illnesses of COVID-19 patients, we then analyzed the relevance of the AKI and the three laboratory indexes with the clinical severity through comparing the incidences of AKI and mean differences of those biomarkers between ICU/severe and non-ICU/non-severe cases. Following the results of the heterogeneity test were all shown as $\mathrm{I}^{2}<50 \%$, we applied the fixed-effect model for further investigations. For AKI, the result from 6 studies including 1813 patients showed that the AKI occurred statistically 
medRxiv preprint doi: https://doi.org/10.1101/2020.05.28.20116400; this version posted June 3, 2020. The copyright holder for this preprint

significantly higher in ICU cases (20.3\%) compared with non-ICU cases (1.3\%) [OR 17.1 95\% CI $(9.65,29.96), Z=9.80, P<0.00001$ ] (Figure 2A). In terms of laboratory results, there were considerable differences between ICU and non-ICU cases in Scr $(\mathrm{MD}=6.09 \mu \mathrm{mol} / \mathrm{L}$, 95\%CI 2.71-9.47, 10 studies, $\mathrm{n}=1064$ ) (Figure 2B), BUN(MD=1.84 $\mu \mathrm{mol} / \mathrm{L}, 95 \% \mathrm{CI} 1.44-2.25$, 7 studies, $\mathrm{n}=701$ ) (Figure 2C) and D-dimer (MD=0.68mg/L, 95\%CI 0.55-0.82, 10 studies, $\mathrm{n}=1478$ ) (Figure 2D). In conclusion, AKI, increased Scr, BUN and D-dimer were prominent features when patients developed into critical conditions (all $\mathrm{P}<0.001$ ) (Figure 2A-D).

\section{Clinical characteristics of kidney impairment}

AKI is a risk factor of proteinuria and subsequently can be developed into chronic kidney disease $(\mathrm{CKD})^{18}$. Here, we sought to further explore the clinical effects of kidney impairment caused by COVID-19, and we analyzed another two clinical features among COVID-19 patients. The results show that the most prevalent of kidney injury comorbidities were proteinuria (42.0\%, 95\%CI 30.4\%-53.7\%) (Figure 3A) and hematuria (30.3\%, 95\%CI 20.6\%40.1\%) (Figure 3B) with high heterogeneity (both $\mathrm{I}^{2}>80 \%$ ).

\section{Sensitivity Analysis and bias assessment}

In the end, the funnel plots displayed symmetrical distributions of the effect sizes of AKI, Scr, BUN and D-dimer, and presented no obvious publication bias (Figure 4A-D).

\section{DISCUSSION}

The COVID-19 has affected hundreds of millions of people posing a huge healthy threaten and bring a major burden to public healthcare institutions around the world. Compared with the other two pathogenic coronaviruses family members SARS-CoV and MERS-CoV, SARS- 
medRxiv preprint doi: https://doi.org/10.1101/2020.05.28.20116400; this version posted June 3, 2020. The copyright holder for this preprint (which was not certified by peer review) is the author/funder, who has granted medRxiv a license to display the preprint in perpetuity. It is made available under a CC-BY-NC-ND 4.0 International license.

$\mathrm{CoV}-2$ is higher contagious causing global pandemic, whereas each of which has its own clinical manifestation. Studies have been reported that SARS-CoV-2 is sharing highly $79.6 \%$ genome sequence identity as well as high molecular structure similarity with SARS-CoV ${ }^{4,19}$. Therefore, SARS-CoV-2 uses ACE2 as a cellular entry receptor as SARS-CoV ${ }^{4,20}$. ACE2 is highly expressed in multiple systems and tissues, mainly in the respiratory, cardiovascular, renal and gastrointestinal systems ${ }^{7}$. In addition to respiratory diseases and cardiac damage caused by SARS-CoV-2 through ACE2, we still need to consider the possibility of kidney effects on COVID-19 patients.

The meta-analysis was based on data from 19 studies with confirmed COVID-19 cases in China. In all cases, men were a more significant population around 55\% than women, which has similar infection characteristics as MERS and SARS ${ }^{21,22}$. Also, aged and people with other comorbidities, especially cardiovascular diseases, are more likely susceptible to COVID-19². Our meta-analysis has shown that the prevalence of AKI is approximately $7.7 \%$, and other laboratory biomarkers reflecting renal injuries such as increased Scr, BUN and D-dimer were presented in $6.6 \%, 6.2 \%, 49.8 \%$, respectively. Moreover, the clinical features of kidney dysfunction are even higher than cardiovascular diseases in COVID-19 patients, proteinuria is $42 \%$ and hematuria is $30.3 \%$, while hypertension and diabetes were showed around $8 \%$ and $5 \%$ in Jing Yang's study'. When compared the ICU/severe and non-ICU/non-severe cases, our results have demonstrated that the AKI happened 17-folds higher in critical condition, while the incidence of acute cardiac injury was around 13-folds higher in severe disease in Bo Li's study $^{8}$. At all, the kidney injury is more susceptibility than cardiac damage so that we should pay more attention to protecting the normal function and recovery of kidney 
medRxiv preprint doi: https://doi.org/10.1101/2020.05.28.20116400; this version posted June 3, 2020. The copyright holder for this preprint

Due to the restriction of clinic information and most of the studies did not include in the death cases and the mortality of COVID-19, the association between kidney impairment and COVID19-induced death was not be analyzed in our meta-analysis. We still need to follow-up those COVID-19 patients in the future, as the most relevant clinical predictors are chronic kidney disease for the death in SARS patients. Therefore, the chronic diseases community will play a critical role in the management and treatment of patients affected by this epidemic disease.

However, there are still some limitations for this meta-analysis. Firstly, due to the information missing from the literature, we hardly could include study compared the complications of kidney injury between ICU/severe and non-ICU/non-severe patients. In which cases, we did not perform sensitivity analysis and subgroup analysis for proteinuria, hematuria or uric acid. Secondly, we found that the high statistic heterogeneity in the prevalence of kidney injury analysis. The reasons are related to the study designs and significant variations among studies in the sample sizes. Thirdly, therapies under investigation for COVID-19 may have kidney side effects as lots of drugs are nephrotoxic such as aminoglycosides, ACE inhibitors and nonsteroidal anti-inflammatory drugs(NSAIDs), we are not sure whether some clinical data we got have such possibility involved, and we could not rule out the influences caused by drugs on kidney during the hospitalization.

There are some explanations for kidney injury during the COVID-19 infection episodes. Firstly, ACE-2 distributes on tubular epithelial cells of the kidney with a higher expression level compared to the lung. Thus, the kidney is also a direct aim organ attacked by SARS-CoV-2 entering into target cells through ACE-2 acting as the way in the lung. Secondly, the crosstalk relationship between lung and kidney. Kidney damage can be caused by circulating 
medRxiv preprint doi: https://doi.org/10.1101/2020.05.28.20116400; this version posted June 3, 2020. The copyright holder for this preprint (which was not certified by peer review) is the author/funder, who has granted medRxiv a license to display the preprint in perpetuity. It is made available under a CC-BY-NC-ND 4.0 International license.

inflammatory factors such as tumor necrosis factor (TNF)- $\alpha$ and interleukin (IL)-6, which are originated from pneumonia, happened in the lung. Furthermore, the local inflammatory response from injury and death renal cells will accelerate damage in the development of AKI as well as other organs ${ }^{24,25}$.

On the other hand, we still need to analyze the reasons accounting for underestimating kidney impairment in COVID-19 patients in clinic. Firstly, the laboratory tests of blood chemistry analysis, including Scr and BUN, will only elevate into abnormal range when kidney lost at least $50 \%$ function because of the potent compensatory ability of kidney. From our results, we also found that the proportions of aberrant urinalysis were more than the percentage of increased plasma biomarkers. Secondly, the difficulty of precise diagnosis of AKI is another possible aspect responsible for the underrating of AKI. The detection rate of AKI mainly depends on the fluctuation of Scr and the frequency of Scr testing. And a higher incidence of AKI will be detected with adjusted denser Scr testing frequency. Therefore, more accurate strategies should be applied to the clinic when considered $\mathrm{AKI}^{26}$.

In conclusion, SARS-CoV-2 causes renal injury progressing to severe AKI. At the same time, AKI is a life-threatening complication associating with a severer condition in COVID-19 patients. Therefore, we should focus more attention to kidney damage at the early stage when patients are confirmed been infected by COVID-19. There are several biomarkers can be used for monitoring the kidney function such as the level fluctuation of creatinine and urine output with the volume and hemodynamic status, and some novel indicators also should be added in for precisely stratifying the AKI severity like TIMP-2 (tissue inhibitor of metalloproteinase 2 
medRxiv preprint doi: https://doi.org/10.1101/2020.05.28.20116400; this version posted June 3, 2020. The copyright holder for this preprint (which was not certified by peer review) is the author/funder, who has granted medRxiv a license to display the preprint in perpetuity. It is made available under a CC-BY-NC-ND 4.0 International license .

(TIMP-2) and insulin-like growth factor binding protein 7(IGFBP7 $)^{27}$. Moreover, to reduce the possibility of developing into critically illness and the mortality risk for COVID-19 patients, applying more protective measures and supportive medication interventions is necessary, which has a significant influence for the kidney care of patients, including but not limited to renal replacement therapies like blood filtering and purification treatments, the application of drugs with mild kidney adverse effects etc.

\section{ACKNOWLEDGEMENTS}

None.

\section{FUNDING SOURCES}

Q.Y. is supported by Chinese Government Scholarship (University Graduate Program) in

Central South University 31801-160170002.

\section{REFERENCES}

1. Huang C, Wang Y, Li X, et al.: Clinical features of patients infected with 2019 novel coronavirus in Wuhan, China. The Lancet 2020; 395:497-506.

2. Wang D, Hu B, Hu C, et al.: Clinical Characteristics of 138 Hospitalized Patients With 2019 Novel Coronavirus-Infected Pneumonia in Wuhan, China. JAMA 2020; 323:1061.

3. Mahase E: Covid-19: WHO declares pandemic because of "alarming levels" of spread, severity, and inaction. BMJ 2020; 368:m1036.

4. Zhou P, Yang X-L, Wang X-G, et al.: A pneumonia outbreak associated with a new coronavirus of probable bat origin. Nature 2020; 579:270-273.

5. Walls AC, Park Y-J, Tortorici MA, Wall A, McGuire AT, Veesler D: Structure, Function, and Antigenicity of the SARS-CoV-2 Spike Glycoprotein. Cell 2020; 181:281-292.e6.

6. Chen N, Zhou M, Dong X, et al.: Epidemiological and clinical characteristics of 99 cases of 2019 novel coronavirus pneumonia in Wuhan, China: a descriptive study. The Lancet 2020; 395:507-513. 
medRxiv preprint doi: https://doi.org/10.1101/2020.05.28.20116400; this version posted June 3, 2020. The copyright holder for this preprint (which was not certified by peer review) is the author/funder, who has granted medRxiv a license to display the preprint in perpetuity. It is made available under a CC-BY-NC-ND 4.0 International license.

7. Hamming I, Timens W, Bulthuis M, Lely A, Navis G, van Goor H: Tissue distribution of ACE2 protein, the functional receptor for SARS coronavirus. A first step in understanding SARS pathogenesis. J Pathol 2004; 203:631-637.

8. Li B, Yang J, Zhao F, Zhi L, Wang X, Liu L, Bi Z, Zhao Y: Prevalence and impact of cardiovascular metabolic diseases on COVID-19 in China. Clin Res Cardiol [Internet] 2020 [cited 2020 Apr 21]; . Available from: http://link.springer.com/10.1007/s00392-020-01626-9

9. Yang J, Zheng Y, Gou X, Pu K, Chen Z, Guo Q, Ji R, Wang H, Wang Y, Zhou Y: Prevalence of comorbidities and its effects in coronavirus disease 2019 patients: A systematic review and metaanalysis. International Journal of Infectious Diseases 2020; 94:91-95.

10. Liang W, Feng Z, Rao S, Xiao C, Xue X, Lin Z, Zhang Q, Qi W: Diarrhoea may be underestimated: a missing link in 2019 novel coronavirus. Gut 2020; :gutjnl-2020-320832.

11. Xiao F, Tang M, Zheng X, Liu Y, Li X, Shan H: Evidence for Gastrointestinal Infection of SARS-CoV-2. Gastroenterology 2020; :S0016508520302821.

12. Anti-2019-nCoV Volunteers, Li Z, Wu M, et al.: Caution on Kidney Dysfunctions of COVID-19 Patients [Internet]. Infectious Diseases (except HIV/AIDS), 2020 Feb. Available from: http://medrxiv.org/lookup/doi/10.1101/2020.02.08.20021212

13. Cheng Y, Luo R, Wang K, Zhang M, Wang Z, Dong L, Li J, Yao Y, Ge S, Xu G: Kidney impairment is associated with in-hospital death of COVID-19 patients [Internet]. Nephrology, 2020 Feb. Available from: http://medrxiv.org/lookup/doi/10.1101/2020.02.18.20023242

14. Wang L, Li X, Chen H, Yan S, Li Y, Li D, Gong Z: SARS-CoV-2 infection does not significantly cause acute renal injury: an analysis of 116 hospitalized patients with COVID-19 in a single hospital, Wuhan, China [Internet]. Infectious Diseases (except HIV/AIDS), 2020 Feb. Available from: http://medrxiv.org/lookup/doi/10.1101/2020.02.19.20025288

15. Stewart LA, Clarke M, Rovers M, Riley RD, Simmonds M, Stewart G, Tierney JF: Preferred Reporting Items for a Systematic Review and Meta-analysis of Individual Participant Data: The PRISMA-IPD Statement. JAMA 2015; 313:1657.

16. Khwaja A: KDIGO clinical practice guidelines for acute kidney injury. Nephron Clin Pract 2012; 120:c179-184.

17. Cate $\mathrm{V}$ ten, Nagler M, Panova-Noeva M, et al.: The diagnostic performance of renal functionadjusted D-dimer testing in individuals suspected of having venous thromboembolism. Haematologica 2019; 104:e424-e427.

18. Parr SK, Matheny ME, Abdel-Kader K, Greevy RA, Bian A, Fly J, Chen G, Speroff T, Hung AM, Ikizler TA, Siew ED: Acute kidney injury is a risk factor for subsequent proteinuria. Kidney International 2018; 93:460-469.

19. Lu R, Zhao X, Li J, et al.: Genomic characterisation and epidemiology of 2019 novel coronavirus: implications for virus origins and receptor binding. Lancet 2020; 395:565-574.

20. Li F, Li W, Farzan M, Harrison SC: Structure of SARS coronavirus spike receptor-binding domain complexed with receptor. Science 2005; 309:1864-1868.

21. Badawi A, Ryoo SG: Prevalence of comorbidities in the Middle East respiratory syndrome coronavirus (MERS-CoV): a systematic review and meta-analysis. International Journal of Infectious Diseases 2016; 49:129-133.

22. Channappanavar R, Fett C, Mack M, Ten Eyck PP, Meyerholz DK, Perlman S: Sex-Based Differences in Susceptibility to Severe Acute Respiratory Syndrome Coronavirus Infection. J Immunol 2017; 198:4046-4053. 
medRxiv preprint doi: https://doi.org/10.1101/2020.05.28.20116400; this version posted June 3, 2020. The copyright holder for this preprint (which was not certified by peer review) is the author/funder, who has granted medRxiv a license to display the preprint in perpetuity. It is made available under a CC-BY-NC-ND 4.0 International license.

23. Zhang J, Dong X, Cao Y, Yuan Y, Yang Y, Yan Y, Akdis CA, Gao Y: Clinical characteristics of 140 patients infected with SARS-CoV-2 in Wuhan, China. Allergy 2020; :all.14238.

24. Joannidis M, Forni LG, Klein SJ, et al.: Lung-kidney interactions in critically ill patients: consensus report of the Acute Disease Quality Initiative (ADQI) 21 Workgroup. Intensive Care Med 2020; 46:654-672.

25. Teixeira JP, Ambruso S, Griffin BR, Faubel S: Pulmonary Consequences of Acute Kidney Injury. Semin Nephrol 2019; 39:3-16.

26. Xu X, Nie S, Liu Z, Chen C, Xu G, Zha Y, Qian J, Liu B, Han S, Xu A, Xu X, Hou FF: Epidemiology and Clinical Correlates of AKI in Chinese Hospitalized Adults. CJASN 2015; 10:1510 1518.

27. Pike F, Murugan R, Keener C, Palevsky PM, Vijayan A, Unruh M, Finkel K, Wen X, Kellum JA: Biomarker Enhanced Risk Prediction for Adverse Outcomes in Critically Ill Patients Receiving RRT. CJASN 2015; 10:1332-1339.

28. zhou H, Zhang Z, Fan H, et al.: Urinalysis, but not blood biochemistry, detects the early renalimpairment in patients with COVID-19 [Internet]. Urology, 2020 Apr. Available from: http://medrxiv.org/lookup/doi/10.1101/2020.04.03.20051722

29. Zhou F, Yu T, Du R, et al.: Clinical course and risk factors for mortality of adult inpatients with COVID-19 in Wuhan, China: a retrospective cohort study. The Lancet 2020; 395:1054-1062.

30. Cai Q, Huang D, Ou P, et al.: COVID-19 in a Designated Infectious Diseases HospitalOutside Hubei Province,China [Internet]. Public and Global Health, 2020 Feb. Available from: http://medrxiv.org/lookup/doi/10.1101/2020.02.17.20024018

31. Guan W, Ni Z, Hu Y, et al.: Clinical Characteristics of Coronavirus Disease 2019 in China. N Engl J Med 2020; :NEJMoa2002032.

32. Lu J, Hu S, Fan R, et al.: ACP risk grade: a simple mortality index for patients with confirmed or suspected severe acute respiratory syndrome coronavirus 2 disease (COVID-19) during the early stage of outbreak in Wuhan, China [Internet]. Infectious Diseases (except HIV/AIDS), 2020 Feb. Available from: http://medrxiv.org/lookup/doi/10.1101/2020.02.20.20025510

33. quan weihe, zheng qingyou, tian jinfei, chen jun, liu zhigang, chen xiangqiu, wu tao, ji ziliang, tang jinqi, chu hao, xu haijia, zhao yong: No SARS-CoV-2 in expressed prostatic secretion of patients with coronavirus disease 2019: a descriptive multicentre study in China [Internet]. Urology, 2020 Mar. Available from: http://medrxiv.org/lookup/doi/10.1101/2020.03.26.20044198

34. Xu Y, Xu Z, Liu X, et al.: Clinical findings in critical ill patients infected with SARS-Cov-2 in Guangdong Province, China: a multi-center, retrospective, observational study [Internet]. Intensive Care and Critical Care Medicine, 2020 Mar. Available from:

http://medrxiv.org/lookup/doi/10.1101/2020.03.03.20030668

35. Chen G, Wu D, Guo W, et al.: Clinical and immunologic features in severe and moderate Coronavirus Disease 2019. Journal of Clinical Investigation [Internet] 2020 [cited 2020 Mar 31]; . Available from: http://www.jci.org/articles/view/137244

36. Liu Y, Sun W, Li J, Chen L, Wang Y, Zhang L, Yu L: Clinical features and progression of acute respiratory distress syndrome in coronavirus disease 2019 [Internet]. Intensive Care and Critical Care Medicine, 2020 Feb. Available from: http://medrxiv.org/lookup/doi/10.1101/2020.02.17.20024166 37. Liu J, Liu Y, Xiang P, et al.: Neutrophil-to-Lymphocyte Ratio Predicts Severe Illness Patients with 2019 Novel Coronavirus in the Early Stage [Internet]. Infectious Diseases (except HIV/AIDS), 2020 Feb. Available from: http://medrxiv.org/lookup/doi/10.1101/2020.02.10.20021584 
medRxiv preprint doi: https://doi.org/10.1101/2020.05.28.20116400; this version posted June 3, 2020. The copyright holder for this preprint

(which was not certified by peer review) is the author/funder, who has granted medRxiv a license to display the preprint in perpetuity.

It is made available under a CC-BY-NC-ND 4.0 International license.

38. lei liu, Jian-ya G: Clinical characteristics of 51 patients discharged from hospital with COVID19 in Chongqing, China [Internet]. Infectious Diseases (except HIV/AIDS), 2020 Feb. Available from: http://medrxiv.org/lookup/doi/10.1101/2020.02.20.20025536

39. Feng Z, Yu Q, Yao S, et al.: Early Prediction of Disease Progression in 2019 Novel Coronavirus Pneumonia Patients Outside Wuhan with CT and Clinical Characteristics [Internet]. Infectious Diseases (except HIV/AIDS), 2020 Feb. Available from:

http://medrxiv.org/lookup/doi/10.1101/2020.02.19.20025296

40. Lu H, Ai J, Shen Y, et al.: A descriptive study of the impact of diseases control and prevention on the epidemics dynamics and clinical features of SARS-CoV-2 outbreak in Shanghai, lessons learned for metropolis epidemics prevention [Internet]. Infectious Diseases (except HIV/AIDS), 2020 Feb. Available from: http://medrxiv.org/lookup/doi/10.1101/2020.02.19.20025031 
medRxiv preprint doi: https://doi.org/10.1101/2020.05.28.20116400; this version posted June 3, 2020. The copyright holder for this preprint (which was not certified by peer review) is the author/funder, who has granted medRxiv a license to display the preprint in perpetuity. It is made available under a CC-BY-NC-ND 4.0 International license.

\section{FIGURE LEGENDS}

Figure 1: PRISMA flowchart of the study selection process

Figure 2: Meta-analysis of incidences of AKI and three laboratory indexes of kidney injury.

Forest plots represent the comparisons of the prevalence of AKI and mean differences (MD) in three laboratory indicators between ICU/severe and non-ICU/non-severe cases. A, serum creatinine (Scr, $\mu \mathrm{mol} / \mathrm{L})$; B, blood urea nitrogen (BUN, $\mu \mathrm{mol} / \mathrm{L})$; C, D-dimer(mg/L).

Figure 3: Meta-analysis of incidences of two clinical characteristics of kidney injury. A, proteinuria; B, hematuria.

Figure 4: Funnel plots of the comparisons of AKI (A), Scr (B), BUN (C) and D-dimer (D) between ICU/severe and non-ICU/severe patients 
medRxiv preprint doi: https://doi.org/10.1101/2020.05.28.20116400; this version posted June 3, 2020. The copyright holder for this preprint (which was not certified by peer review) is the author/funder, who has granted medRxiv a license to display the preprint in perpetuity. It is made available under a CC-BY-NC-ND 4.0 International license.

Table 1 Study characteristics including number, location, age, sex and Kidney impairment of patients of the 19 included studies

\begin{tabular}{|c|c|c|c|c|c|c|c|c|c|c|c|}
\hline \multirow[b]{2}{*}{ Studies } & \multirow{2}{*}{$\begin{array}{l}\text { Study } \\
\text { period }\end{array}$} & \multirow{2}{*}{$\begin{array}{c}\text { Number } \\
\text { of } \\
\text { patients }\end{array}$} & \multirow[b]{2}{*}{ location } & \multirow[b]{2}{*}{$\begin{array}{c}\text { Mean age } \\
\text { (SD) }\end{array}$} & \multirow[b]{2}{*}{$\begin{array}{c}\text { Sex } \\
\text { (male,\%) }\end{array}$} & \multicolumn{6}{|c|}{ Kidney metabolic diseases } \\
\hline & & & & & & $\begin{array}{c}\text { AKI } \\
\%\end{array}$ & $\begin{array}{c}\text { Increased } \\
\text { Scr } \%\end{array}$ & $\begin{array}{c}\text { Increased } \\
\text { BUN \% }\end{array}$ & $\begin{array}{c}\text { Increased } \\
\text { D-dimer \% }\end{array}$ & $\begin{array}{c}\text { Proteinuria } \\
\%\end{array}$ & $\begin{array}{c}\text { Hematuria } \\
\%\end{array}$ \\
\hline Zhen Li et al. ${ }^{12}$ & $\begin{array}{l}1 / 6 / 2020- \\
2 / 21 / 2020\end{array}$ & 193 & $\begin{array}{l}\text { Wuhan, } \\
\text { Huangshi, } \\
\text { Chongqing }\end{array}$ & $56.7(15.6)$ & $95(49 \%)$ & 28 & 10 & 14 & 59 & 59 & 44 \\
\hline Yichun Cheng et al. ${ }^{13}$ & $\begin{array}{l}1 / 28 / 2020- \\
2 / 11 / 2020\end{array}$ & 710 & Wuhan & $61.7(14.8)$ & $374(52.7 \%)$ & 3.2 & 15.5 & - & 77.7 & 44.01 & 26.9 \\
\hline Haifeng Zhou et al. ${ }^{28}$ & $\begin{array}{l}2 / 2 / 2020- \\
2 / 29 / 2020\end{array}$ & 178 & Wuhan & $47.7(19.3)$ & $72(40.4 \%)$ & - & 0 & 2.8 & - & 34.9 & 28.9 \\
\hline Fei Zhou et al. ${ }^{29}$ & $\begin{array}{l}12 / 29 / 2019 \\
-1 / 31 / 2020\end{array}$ & 191 & Wuhan & $56.3(15.6)$ & $119(62 \%)$ & 15 & 4 & - & 68 & - & - \\
\hline Nanshan Chen et al. ${ }^{6}$ & $\begin{array}{l}1 / 1 / 2020- \\
1 / 20 / 2020\end{array}$ & 99 & Wuhan & $55.5(13.1)$ & $67(68 \%)$ & 3 & - & 6 & 36 & - & - \\
\hline Chaolin Huang et al. ${ }^{1}$ & $\begin{array}{c}12 / 16 / 2019 \\
-1 / 2 / 2020\end{array}$ & 41 & Wuhan & $49.3(12.6)$ & $30(73 \%)$ & 7 & 10 & - & - & - & - \\
\hline Qingxian Cai et al..$^{30}$ & $\begin{array}{c}1 / 11 / 2020- \\
2 / 6 / 2020\end{array}$ & 298 & Shenzhen & $47(20.7)$ & $149(50 \%)$ & 5.7 & 4.4 & 4 & 35.7 & - & - \\
\hline Weijie Guan et al. ${ }^{31}$ & $\begin{array}{l}12 / 11 / 2019 \\
-1 / 29 / 2020\end{array}$ & 1099 & Nationwide & $46.7(17.0)$ & $637(58 \%)$ & 0.5 & 1.6 & - & 46.4 & - & \\
\hline Dawei Wang et al. ${ }^{2}$ & $\begin{array}{l}1 / 1 / 2020- \\
1 / 28 / 2020\end{array}$ & 138 & Wuhan & $55.3(19.3)$ & $75(54.3 \%)$ & 3.6 & - & - & - & - & - \\
\hline Jiatao Lu et al..$^{32}$ & $\begin{array}{c}1 / 21 / 2020- \\
2 / 5 / 2020\end{array}$ & 577 & Wuhan & $53.3(20)$ & $254(44 \%)$ & - & 3 & - & 33.5 & - & - \\
\hline Jinjin Zhang et al. ${ }^{23}$ & $\begin{array}{c}1 / 16 / 2020- \\
2 / 3 / 2020\end{array}$ & 140 & Wuhan & $57.2(14.8)$ & $71(50.7 \%)$ & - & - & - & 43.2 & - & - \\
\hline Weihe Quan et al. ${ }^{33}$ & $\begin{array}{c}2 / 25 / 2020- \\
3 / 13 / 2020\end{array}$ & 18 & $\begin{array}{c}\text { Shenzhen, } \\
\text { Wuhan }\end{array}$ & $60.3(15.3)$ & NA & - & - & - & - & 22.2 & 16.7 \\
\hline Yonghao Xu et al. ${ }^{34}$ & $2 / 28 / 2020$ & 45 & Guangdong & $56.7(15.4)$ & $29(64.4 \%)$ & 15.6 & - & - & - & - & - \\
\hline Guang Chen et al..$^{35}$ & $\begin{array}{l}12 / 19 / 2019 \\
-1 / 27 / 2020\end{array}$ & 21 & Wuhan & $57(11.1)$ & $17(81 \%)$ & - & - & - & - & - & - \\
\hline Yanli Liu et al. ${ }^{36}$ & $\begin{array}{l}1 / 2 / 2020 \\
2 / 1 / 2020\end{array}$ & 109 & Wuhan & $54.7(17.0)$ & $59(54.1 \%)$ & - & - & - & - & - & - \\
\hline Jingyuan Liu et al. ${ }^{37}$ & $\begin{array}{l}1 / 13 / 2020- \\
1 / 31 / 2020\end{array}$ & 61 & Beijing & $42.3(15.7)$ & $31(50.8 \%)$ & - & - & - & - & - & - \\
\hline Lei Liu et al. ${ }^{38}$ & $\begin{array}{c}1 / 11 / 2020- \\
2 / 6 / 2020\end{array}$ & 51 & Chongqing & $43.3(12.6)$ & $32(63 \%)$ & - & - & - & - & - & - \\
\hline Zhichao Feng et al. ${ }^{39}$ & $\begin{array}{c}1 / 17 / 2020- \\
2 / 1 / 2020\end{array}$ & 141 & Hunan & $44.3(15.3)$ & $72(51.1 \%)$ & - & - & - & - & - & - \\
\hline
\end{tabular}


medRxiv preprint doi: https://doi.org/10.1101/2020.05.28.20116400; this version posted June 3, 2020. The copyright holder for this preprint (which was not certified by peer review) is the author/funder, who has granted medRxiv a license to display the preprint in perpetuity. It is made available under a CC-BY-NC-ND 4.0 International license.

AKI, acute kidney injury; Scr serum creatinine; BUN blood urea nitrogen.

\section{Figure 1}
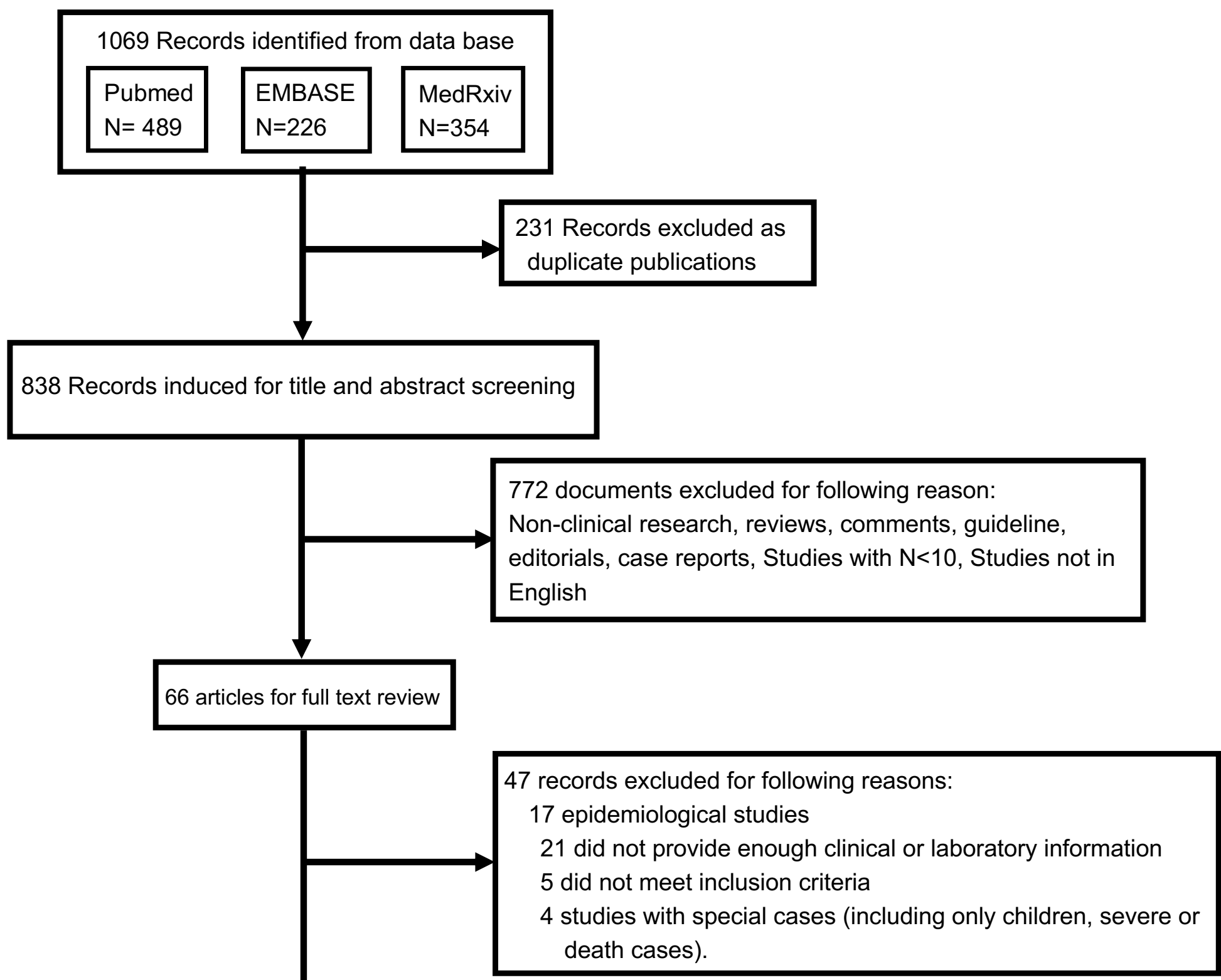

19 studies included for the present meta-analysis 
medRxiv preprint doi: https://doi.org/10.1101/2020.05.28.20116400; this version posted June 3, 2020. The copyright holder for this preprint (which was not certified by peer review) is the author/funder, who has granted medRxiv a license to display the preprint in perpetuity. It is made available under a CC-BY-NC-ND 4.0 International license.

\section{Figure 2}

\section{A Acute kidney injury}

Studies

Zhen Li et al. 2020

Dawei Wang et al. 2020

Weijie Guan et al. 2020

Fei Zhou et al. 2020

Chaolin Huang et al. 2020

Yonghao Xu et al. 2020

Nanshan Chen et al. 2020

Yichun Cheng et al. 2020

Qingxian Cai et al. 2020
Estimate (95\% C.I.) Ev/Trt

$0.285(0.221,0.349) \quad 55 / 193$

$0.036(0.005,0.067) \quad 5 / 138$

$0.005(0.001,0.010) \quad 6 / 1099$

$0.147(0.096,0.197) \quad 28 / 191$

$0.073(0.000,0.153) \quad 3 / 41$

$0.156(0.050,0.261) \quad 7 / 45$

$0.030(0.000,0.064) \quad 3 / 99$

$0.031(0.018,0.044) 22 / 710$

$0.057(0.031,0.083) 17 / 298$

Overall (I^2=94 \%,P<0.001) $0.077 \quad(0.045,0.109) \quad 146 / 2814$



ICU Non-ICU

Odds Ratio

Odds Ratio

Study or Subgroup Events Total Events Total Weight M-H, Fixed, 95\% CI

$\begin{array}{lllllll}\text { Chaolin Huang et al. } & 3 & 13 & 0 & 28 & 4.3 \% & 19.00[0.90,399.79]\end{array}$

Dawei ming et al.

Qingxian Cai et al.

Weijie Guan et al.

Yonghao $x u$ et al.

Zhen Li et al.

$3 \quad 36$

2102

$16.7 \% \quad 4.55[0.73,28.39]$

$13 \quad 58$

4240

$21.0 \% \quad 17.04[5.32,54.65]$

$5 \quad 173$

1926

$\begin{array}{lll}5.3 \% & 27.53 & {[3.20,237.12]}\end{array}$

$\begin{array}{lllllll}7 & 20 & 0 & 24 & 5.1 \% & 27.22 & {[1.44,514.31]}\end{array}$

Total $(95 \% \mathrm{Cl})$

Total events

365 74

$1448 \quad 100.0 \%$

$17.01[9.65,29.96]$

Heterogeneity. $\mathrm{Chi}^{2}=2.36$, df $=5(\mathrm{P}=0.80) ; \mathrm{I}^{2}=0 \%$

Test for overall effect: $Z=9.80(P<0.00001$ )

19

\section{5]}

M-H, Fixed, $95 \% \mathrm{CI}$


medRxiv preprint doi: https://doi.org/10.1101/2020.05.28.20116400; this version posted June 3, 2020. The copyright holder for this preprint (which was not certified by peer review) is the author/funder, who has granted medRxiv a license to display the preprint in perpetuity.

\section{B Serum creatinine}

\section{Studies}

Zhen Li et al. 2020

Weijie Guan et al. 2020

Fei Zhou et al. 2020

Chaolin Huang et al. 2020

Yichun Cheng et al. 2020

Qingxian Cai et al. 2020

Jiatao Lu et al. 2020

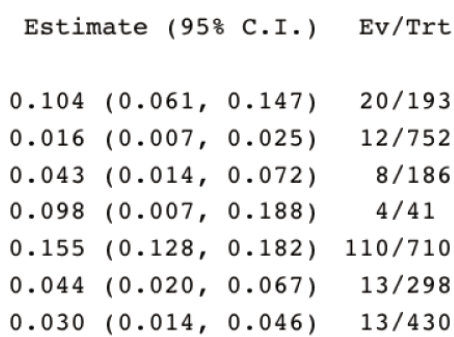

Overall (I^2=94 \%,P<0.001) $0.066(0.030,0.102) \quad 180 / 2610$

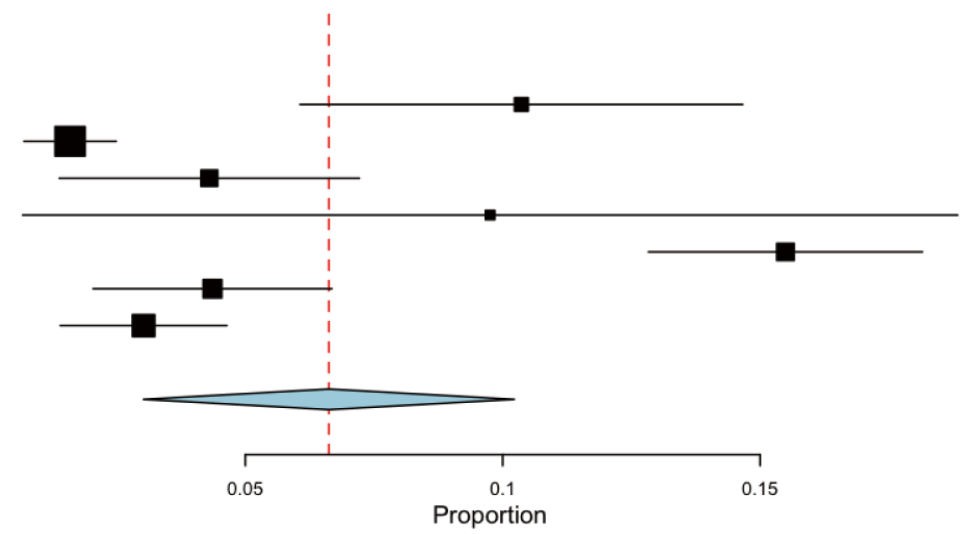

Proportion



\section{Blood urea nitrogen}

\section{Studies}

\section{Zhen Li et al. 2020}

Nanshan Cheng et al. 2020

Qingxian Cai et al. 2020

Haifeng Zhou et al. 2020
Estimate (95\% C.I.) Ev/Trt

$0.140(0.091,0.189) 27 / 193$

$0.061(0.014,0.108) 6 / 99$

$0.040(0.018,0.063) 12 / 298$

$0.028(0.004,0.052) 5 / 178$

Overall $\left(I^{\wedge} 2=82 \quad \%, P<0.001\right) \quad 0.062(0.024,0.101) \quad 50 / 768$

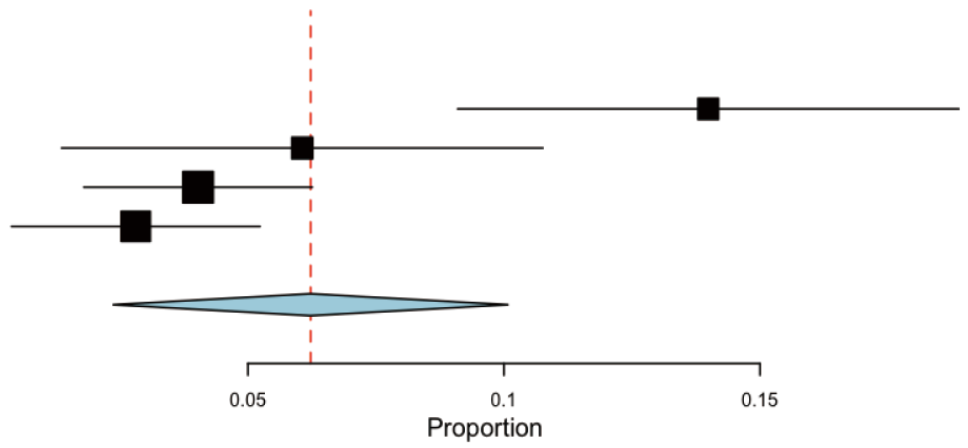

Proportion

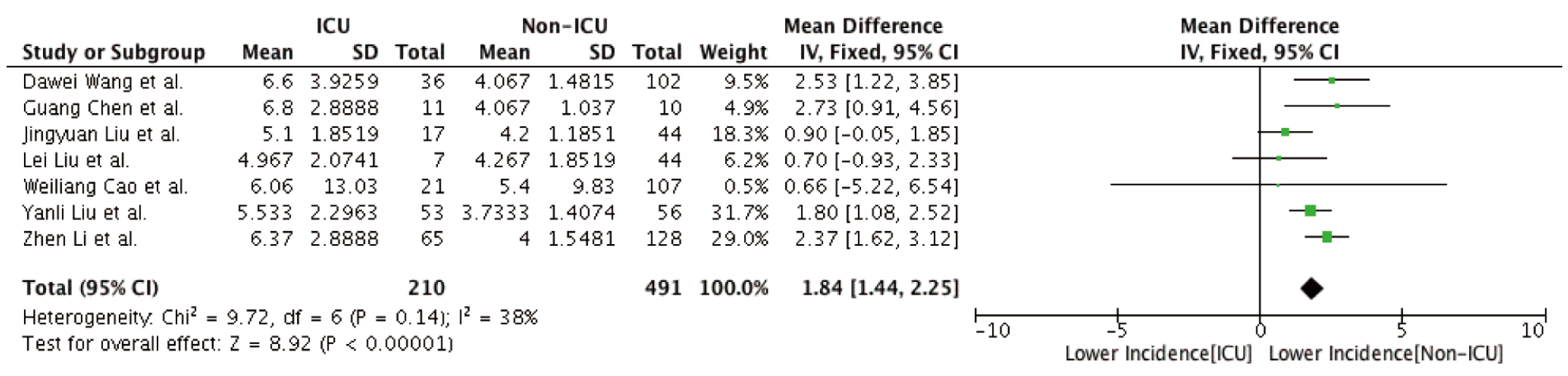


medRxiv preprint doi: https://doi.org/10.1101/2020.05.28.20116400; this version posted June 3, 2020. The copyright holder for this preprint (which was not certified by peer review) is the author/funder, who has granted medRxiv a license to display the preprint in perpetuity. It is made available under a CC-BY-NC-ND 4.0 International license.

\section{D-dimer}

\section{Studies}

Zhen Li et al. 2020

Weijie Guang et al. 2020

Fei Zhou et al. 2020

Nanshan Chen et al. 2020

Yichun Cheng et al. 2020

Qingxian Cai et al. 2020

Jiatao Lu et al. 2020

Jinjin Zhang et al. 2020
Estimate (95\% C.I.) Ev/Trt

$0.588(0.516,0.659) \quad 107 / 182$

$0.464(0.423,0.506) 260 / 560$

$0.680(0.611,0.750) \quad 117 / 172$

$0.364(0.269,0.458) \quad 36 / 99$

$0.778(0.747,0.810) \quad 520 / 668$

$0.332(0.279,0.386) \quad 99 / 298$

$0.335(0.285,0.385) \quad 115 / 343$

$0.432(0.324,0.540) \quad 35 / 81$

Overall $\left(\left.\right|^{\wedge} 2=98 \quad \%, P<0.001\right) \quad 0.498 \quad(0.354,0.642) \quad 1289 / 2403$

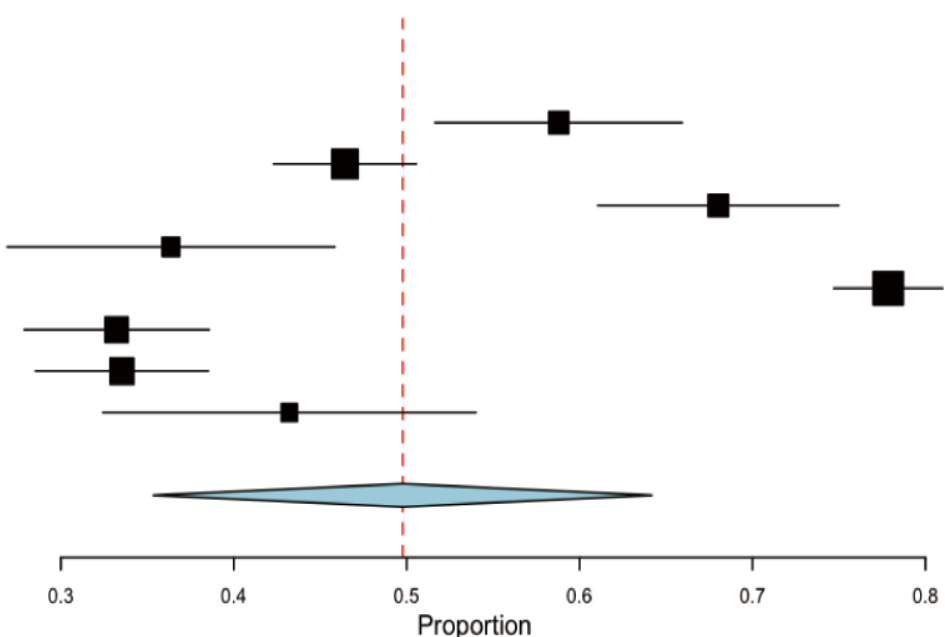

Mean Difference

Mean Difference

IV, Fixed, $95 \% \mathrm{Cl}$

IV, Fixed, $95 \% \mathrm{CI}$




medRxiv preprint doi: https://doi.org/10.1101/2020.05.28.20116400; this version posted June 3, 2020. The copyright holder for this preprint (which was not certified by peer review) is the author/funder, who has granted medRxiv a license to display the preprint in perpetuity. It is made available under a CC-BY-NC-ND 4.0 International license.

\section{Figure 3}

\section{A Proteinuria}

Studies

Zhen Li et al. 2020

Yichun Cheng et al. 2020

Weihe Quan et al. 2020

Haifeng Zhou et al. 2020
Estimate (95\% C.I.) Ev/Trt

$0.589(0.504,0.674) \quad 76 / 129$

$0.440(0.394,0.486) 195 / 443$

$0.222(0.030,0.414) \quad 4 / 18$

$0.349(0.247,0.452) \quad 29 / 83$

Overall $\left(\left.\right|^{\wedge} 2=84 \quad \%, P<0.001\right) \quad 0.420(0.304,0.537) \quad 304 / 673$

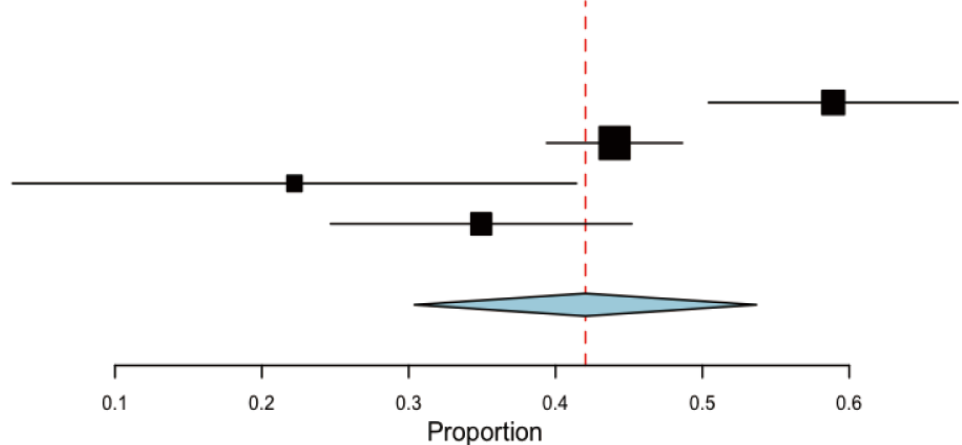

\section{B Hematuria}

Studies

Zhen Li etal. 2020

Yichun Cheng et al. 2020

Weihe Quan et al. 2020

Haifeng Zhou et al. 2020
Estimate (95\% C.I.) Ev/Trt

$0.442(0.356,0.528) \quad 57 / 129$

$0.269(0.227,0.310) \quad 119 / 443$

$0.167(0.000,0.339) \quad 3 / 18$

$0.289(0.192,0.387) \quad 24 / 83$

Overall $\left(\left.\right|^{\wedge} 2=80 \quad \%, P=0.002\right) \quad 0.303 \quad(0.206,0.401) \quad 203 / 673$

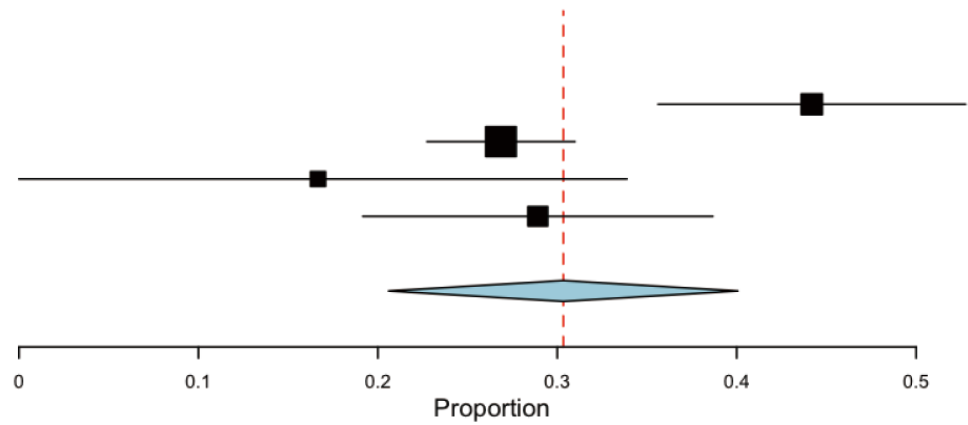


medRxiv preprint doi: https://doi.org/10.1101/2020.05.28.20116400; this version posted June 3, 2020. The copyright holder for this preprint (which was not certified by peer review) is the author/funder, who has granted medRxiv a license to display the preprint in perpetuity. It is made available under a CC-BY-NC-ND 4.0 International license.

Figure 4

\section{A Acute kidney injury}

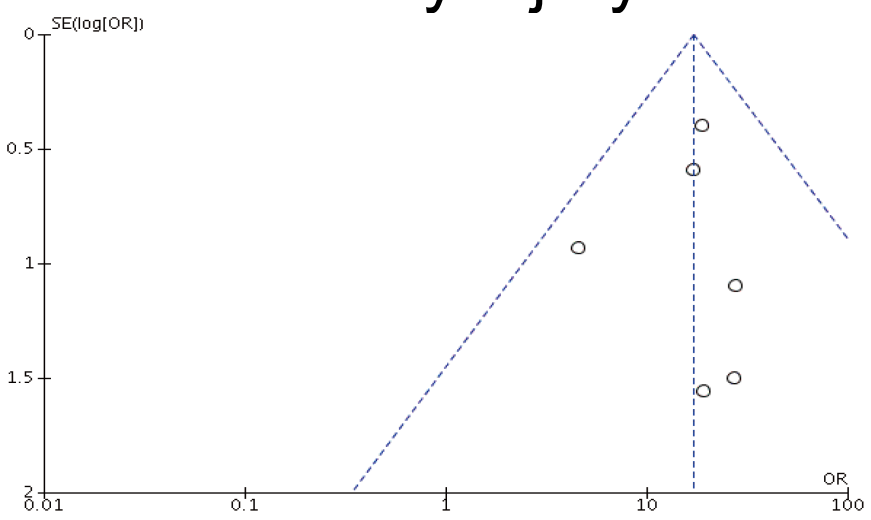

\section{Blood urea}

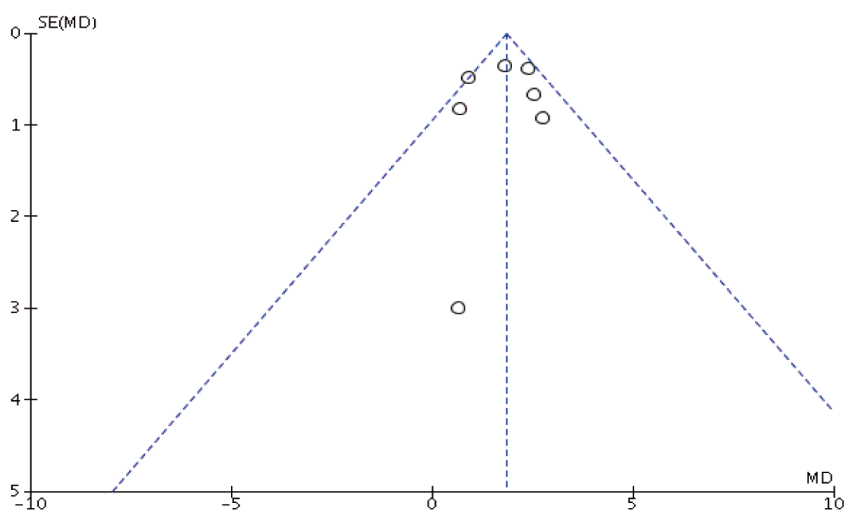

\section{B Serum creatinine}

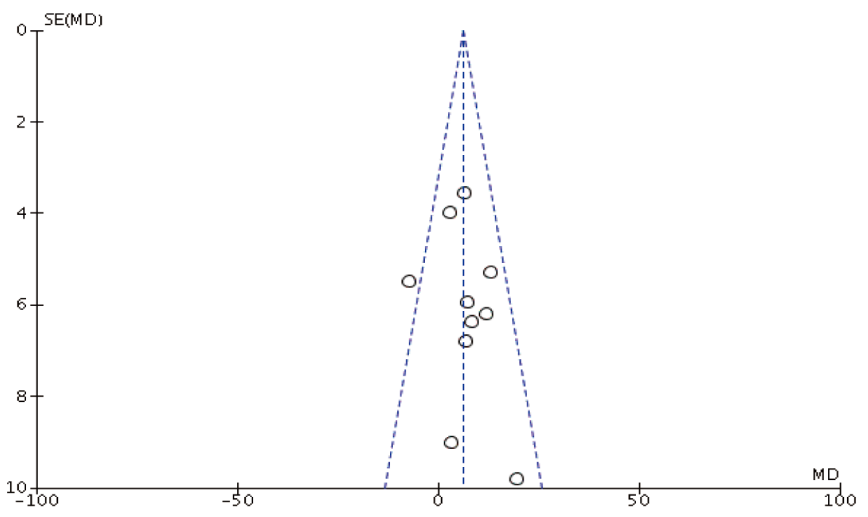

D D-dimer

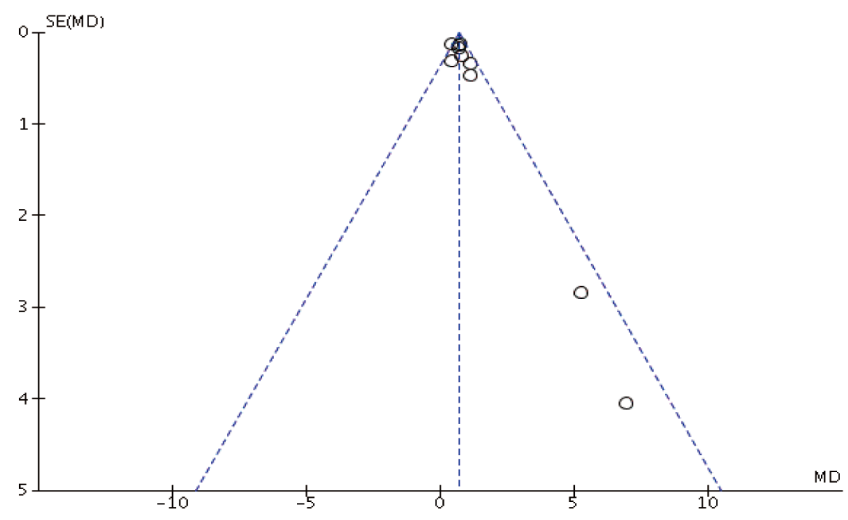

